\title{
Metabolic syndrome in children with chronic kidney disease and after renal transplantation
}

\author{
Mieczysław Litwin • Anna Niemirska
}

Received: 7 February 2013 /Revised: 29 March 2013 /Accepted: 25 April 2013 /Published online: 13 June 2013

(C) The Author(s) 2013. This article is published with open access at Springerlink.com

\begin{abstract}
Visceral obesity and metabolic abnormalities typical for metabolic syndrome (MS) are the new epidemic in adolescence. MS is not only the risk factor for cardiovascular disease but also for chronic kidney disease (CKD). Thus, there are some reasons to recognize MS as a new challenge for pediatric nephrologists. First, hypertensive and diabetic nephropathy, the main causes of CKD in adults, both share the same pathophysiological abnormalities associated with visceral obesity and insulin resistance and have their origins in childhood. Secondly, as the obesity epidemic also affects children with $\mathrm{CKD}$, MS emerges as the risk factor for progression of CKD. Thirdly, metabolic abnormalities typical for MS may pose additional risk for cardiovascular morbidity and mortality in children with CKD. Finally, although the renal transplantation reverses uremic abnormalities it is associated with an exposure to new metabolic risk factors typical for MS and MS has been found to be the risk factor for graft loss and cardiovascular morbidity after renal transplantation. MS is the result of imbalance between dietary energy intake and expenditure inducing disproportionate fat accumulation. Thus, the best prevention and treatment of MS is physical activity and maintenance of proper relationship between lean and fat mass.
\end{abstract}

Keywords Metabolic syndrome $\cdot$ Chronic kidney disease Renal transplantation $\cdot$ Hypertension $\cdot$ Children

\section{Introduction}

The association between obesity, metabolic abnormalities such as hyperglycemia, dyslipidemia, and cardiovascular

M. Litwin $(\varangle) \cdot$ A. Niemirska

Department of Nephrology and Arterial Hypertension,

The Children's Memorial Health Institute, Warsaw, Poland

e-mail: m.litwin@czd.pl disease (CVD) has been described almost 100 years ago and later on confirmed in the first reports from the Framingham study [1]. In the late eighties of XX century Reaven described pathological link explaining the pathogenesis of CVD associated with obesity, metabolic abnormalities and elevated blood pressure, and indicated the central role of hyperinsulinemia and insulin resistance (IR) [2]. The first name of this abnormality was syndrome X, other names used were: cardiometabolic syndrome, Reaven's syndrome, beer belly syndrome, cardiovascular dysmetabolic syndrome, IR syndrome, and most commonly used nowadays, metabolic syndrome (MS). The definition of MS is based on the finding of at least three abnormalities such as obesity, elevated blood pressure, low-HDL cholesterol, hypertriglyceridemia, and hyperglycemia. However, it has been shown that MS is associated not only with the amount of fat tissue but rather with its distribution and relationship between fat and lean body mass (LBM) [3-6]. Moreover, MS may concern lean subjects with a relatively increased amount of visceral fat and decreased amount of subcutaneous fat. Thus, the main contributor of the MS and cardiovascular (CV) risk is disturbed body composition and visceral adiposity [4]. Currently, there are two most widely used definitions of MS set out by the National Cholesterol Education Program Adult Treatment Panel III (ATP III) and the International Diabetes Federation (IDF) (Table 1). The main difference between them is the lack of visceral obesity as an obligatory criterion in the ATP III definition, and the crucial role of visceral obesity as an obligatory criterion in the IDF definition. It causes discrepancies in results of studies using different definitions [7]. Because of the instability of metabolic abnormalities accompanying obesity in children, an improvement with weight loss or increase of LBM at puberty and very low prevalence of CVD in childhood, the diagnosis of MS in children and adolescents was questioned. However, pediatric obesity epidemic, increase of blood pressure in childhood population and finding that 
Table 1 Definitions of metabolic syndrome issued by Adult Treatment Panel (ATP) and International Diabetes Federation (IDF)

International Diabetes Federation
The US National Cholesterol Education Program Adult Treatment Panel III

Central obesity (defined as waist circumference with ethnicity-specific values)

AND any two of the following:

-Triglycerides: $>150 \mathrm{mg} / \mathrm{dl}(1.7 \mathrm{mmol} / \mathrm{l})$, or specific treatment for this lipid abnormality

•HDL cholesterol: $<40 \mathrm{mg} / \mathrm{dl}(1.03 \mathrm{mmol} / \mathrm{l})$ in males, $<50 \mathrm{mg} / \mathrm{dl}(1.29 \mathrm{mmol} / \mathrm{l})$

in females, or specific treatment for this lipid abnormality

-Systolic $\mathrm{BP}>130$ or diastolic $\mathrm{BP}>85 \mathrm{mmHg}$, or treatment

of previously diagnosed hypertension

•Fasting plasma glucose (FPG): >100 mg/dl (5.6 mmol/l),

or previously diagnosed type 2 diabetes

If FPG is $>5.6 \mathrm{mmol} / 1$ or $100 \mathrm{mg} / \mathrm{dl}$, an oral glucose tolerance test is strongly recommended, but is not necessary to define presence of the syndrome

If BMI is $>30 \mathrm{~kg} / \mathrm{m}^{2}$, central obesity can be assumed and waist

circumference does not need to be measure

\author{
At least three of the following: \\ -Central obesity: waist circumference $\geq 102 \mathrm{~cm}$ or \\ 40 inches (male), $\geq 88 \mathrm{~cm}$ or 36 inches (female) \\ -Dyslipidemia: $\mathrm{TG} \geq 1.7 \mathrm{mmol} / \mathrm{l}(150 \mathrm{mg} / \mathrm{dl})$ \\ -Dyslipidemia: HDL-C $<40 \mathrm{mg} / \mathrm{dl}$ (male), \\ $<50 \mathrm{mg} / \mathrm{dl}$ (female) \\ $\cdot$ Blood pressure $\geq 130 / 85 \mathrm{mmHg}$ \\ -Fasting plasma glucose $\geq 6.1 \mathrm{mmol} / 1(110 \mathrm{mg} / \mathrm{dl})$
}

$H D L$ high-density lipoprotein; $B P$ blood pressure; $B M I$ body mass index

metabolic abnormalities and MS are the dominant main intermediate phenotype of primary hypertension $(\mathrm{PH})$ in children caused the greater awareness of MS in childhood $[8,9]$. Unfortunately, the uniform definition of MS was still lacking and even more than 40 different definitions of MS were used in pediatric studies [7]. In 2007, the IDF published pediatric definition based on age-related cut-offs for diagnosis of MS (Table 2) [10]. According to the IDF, MS can be diagnosed in children older than 10 years when at least three criteria are present with an enlarged waist circumference (WC) as the obligatory criterion.

MS is a challenge for pediatric nephrologists because of several reasons. Firstly, the main causes of chronic kidney disease (CKD) in adults, i.e., hypertensive and diabetic nephropathy, share the same pathophysiological abnormalities associated with visceral obesity and IR, both have origins in childhood and obesity-related nephropathy is now more often diagnosed in children [11-15]. Secondly,

Table 2 Definition of metabolic syndrome in children - IDF criteria

\begin{tabular}{|c|c|c|c|c|c|}
\hline $\begin{array}{l}\text { Age group } \\
\text { (years) }\end{array}$ & Obesity (WC) & Triglycerides & HDL-C & Blood pressure & $\begin{array}{l}\text { Glucose }(\mathrm{mmol} / \mathrm{l}) \\
\text { or T2DM }\end{array}$ \\
\hline 6 to $<10$ & $\geq 90$ th percentile & \multicolumn{4}{|c|}{$\begin{array}{l}\text { Metabolic syndrome cannot be diagnosed, but further measurements should } \\
\text { be made if there is a family history of metabolic syndrome, T2DM, } \\
\text { dyslipidemia, cardiovascular disease, hypertension, and/or obesity }\end{array}$} \\
\hline 10 to $<16$ & $\begin{array}{l}\geq 90 \text { th percentile or } \\
\text { adult cut-off if lower }\end{array}$ & $\begin{array}{l}\geq 1.7 \mathrm{mmol} / \mathrm{l} \\
(\geq 150 \mathrm{mg} / \mathrm{dl})\end{array}$ & $\begin{array}{l}<1.03 \mathrm{mmol} / \mathrm{l} \\
(<40 \mathrm{mg} / \mathrm{dl})\end{array}$ & $\begin{array}{l}\text { Systolic } \\
\geq 130 \text { and/or } \\
\quad \text { diastolic } \geq 85 \mathrm{mmHg}\end{array}$ & $\begin{array}{l}\geq 5.6 \mathrm{mmol} / 1 \\
(100 \mathrm{mg} / \mathrm{dl})(\mathrm{If} \geq 5.6 \mathrm{mmol} / \mathrm{l} \\
\text { or known T2DM recommend } \\
\text { an OGTT) }\end{array}$ \\
\hline$>16$ & $\begin{array}{l}\text { Use existing IDF criteri } \\
\text { Central obesity (definec } \\
\text { for Europid women, } \\
\text { plus any two of the foll } \\
\text { - raised triglycerides: } \geq \\
\text { reduced HDL-cholester } \\
\text { ( }<50 \mathrm{mg} / \mathrm{dl} \text { ) in females, } \\
\text { - raised blood pressure: } \\
\text { of previously diagnos } \\
\text { - impaired fasting glyce } \\
\text { ( } \geq 100 \mathrm{mg} / \mathrm{dl} \text { ), or previo }\end{array}$ & $\begin{array}{l}\text { adults: } \\
\text { waist circumfer } \\
\text { ethnicity specif } \\
\text { g four factors: } \\
\mathrm{mmol} / 1 \\
1.03 \mathrm{mmol} / 1(< \\
\text { pecific treatme } \\
\text { olic } \mathrm{BP} \geq 130 \mathrm{o} \\
\text { ypertension } \\
\text { (IFG): fasting } \\
\text { diagnosed type }\end{array}$ & $\begin{array}{l}\mathrm{ng} / \mathrm{dl} \text { ) in males } \\
\text { these lipid abs } \\
\text { astolic } \mathrm{BP} \geq 85 \\
\text { na glucose (FPC } \\
\text { liabetes }\end{array}$ & $\begin{array}{l}<1.29 \mathrm{mmol} / 1 \\
\text { alities } \\
\mathrm{Hg} \text {, or treatment } \\
5.6 \mathrm{mmol} / 1\end{array}$ & \\
\hline
\end{tabular}

$I D F$ International Diabetes Federation; $W C$ waist circumference; $H D L$ high-density lipoprotein 
as the obesity epidemic has also reached children with CKD, MS may accelerate the progression of CKD. Thirdly, CV complications are the main cause of morbidity and mortality in children with CKD and MS may pose additional risk. Finally, although the renal transplantation (Rtx) reverses uremic abnormalities, it is associated with immunosuppressive drug-induced metabolic risk factors.

\section{Pathogenesis of metabolic syndrome}

The main abnormalities in MS include: IR, inflammation, endothelial dysfunction, oxidative stress, activation of the renin-angiotensin-aldosterone system (RAAS) and sympathetic nervous system. Caloric excess with dietary factors such as fructose, trans-unsaturated fatty acids, branched-chain amino acids, and reduced mitochondrial potential are implicated in the pathophysiology of MS. The dominant pathophysiological feature of MS is IR in the liver, adipose tissue, and skeletal muscles [16]. Normally, insulin promotes glucose uptake into muscles, adipocytes, and hepatocytes and inhibits lipolysis in the adipose tissue. It also inhibits gluconeogenesis in the liver, where insulin-induced phosphorylation of a forkhead box protein $\mathrm{O} 1$ (FoxO1) prevents the expression of genes required for gluconeogenesis. Insulin also stimulates the activation of the transcription factor SREBP-1c, leading to transcription of genes required for triglycerides (TTG) and fatty acids (FA) production. Hepatic IR selectively removes the blockade of FoxO1 by insulin what increases gluconeogenesis and increases activation of SREBP-1c. The end result is increased synthesis of FA and TTG. Because of IR, insulin is unable to suppress lipolysis in the adipose tissue. It results in the release of more free FA into the plasma. The "portal theory" of MS is based on the phenomenon of venous drainage of the visceral adipose tissue directly into the portal system. The excess visceral fat causes the liver to be flushed with FA, which further enhances IR. The increased amount of free FA must be oxidized or stored and the excess TTG is secreted as very low density lipoprotein (VLDL). In muscles, IR reduces glucose uptake. IR is also modulated by hyperleptinemia or leptin resistance, adiposity-induced inflammation, and endothelial dysfunction [16].

Oxidative stress, probably as a secondary phenomenon, plays a significant role in the pathogenesis of childhood MS $[17,18]$. High glucose and FA levels increase mitochondrial reactive oxygen species in endothelial cells, which may contribute to tissue dysfunction by dysregulation of signaling pathways or by oxidative damage to biological structures. Hyperleptinemia and angiotensin II activate the sympathetic nervous system. It decreases muscle blood flow, increases oxidative stress and insulin resistance. Specifically, angiotensin II inhibits insulin-mediated phosphatidylinositol-3-kinase. It leads to IR and lower glucose uptake, and to decreased endothelial nitric oxide production [19]. Moreover, RAAS is involved in activation of both inflammation, IR, and oxidative stress. This phenomenon has been shown in spontaneously hypertensive rat (SHR), which is a model of genetic hypertension that allows a study of primary hypertension. It was shown that SHR fed a high-fructose diet developed MS, subclinical inflammation, and oxidative stress greater than in SHR fed a normal diet [20]. Studies in children with PH have shown that subclinical inflammatory activity is associated with MS [21]. Moreover, after 1 year of non-pharmacological and pharmacological treatment with the use of angiotensin convertase inhibitors (ACEi) or angiotensin receptor blockers (ARB), the prevalence of MS decreased by $50 \%$, immune activity normalized, and regression of target organ damage correlated with the decrease of WC [6]. These findings indicate strong synergy between visceral obesity/altered body composition, IR, oxidative stress, and inflammatory activation [22].

$\mathrm{CKD}$ and uremia modulate the above-mentioned metabolic and immune mechanisms by influencing the secretion of appetite-regulating hormones such as leptin, ghrelin, obestatin, and adiponectin [23]. CKD leads to changes in plasma levels of these hormones due to retention and altered metabolism. There are only a few pediatric studies analyzing relationships among appetite regulating hormones in children with CKD. In addition, they are biased by significant differences in body mass index (BMI) between healthy control children and CKD children. Nevertheless, serum levels of total ghrelin, an orexigenic and anti-inflammatory hormone, were significantly increased in children with CKD and on dialysis in comparison with healthy control children and children after Rtx [24]. However, plasma levels of acylated ghrelin (the active form of the hormone) were the same as in the control group, whereas the deacylated form of ghrelin was increased [25]. In contrast to acylated ghrelin, desacylated ghrelin is associated with malnutrition. Similarly, obestatin (an antiorexigenic hormone) levels were increased and leptin levels were the same as in the control group despite significantly lower BMI of children with CKD. It was shown that increased leptin levels were associated with fat mass, local and systemic inflammation, and MS in dialyzed patients [26-28]. Because obestatin is an antiorexigenic hormone and leptin is both an antiorexigenic and pro-inflammatory hormone, such alterations indicate that in CKD, metabolic equilibrium is moved towards anorexigenic, pro-inflammatory, and IR effects.

Recently, new hypotheses linking alterations in central nervous system regulation of cardiovascular system and immuno-metabolic abnormalities in the form of MS have been proposed [29, 30]. In short, there is evidence that increased sympathetic activity from cardiovascular networks in the brain, as is present during chronic stress or in depression, is associated with the development of obesity, and visceral obesity in particular, and immune activation 
and cytokines secretion may have direct effect on central sympathetic activation.

\section{The pathological basis of cardiovascular complications in chronic kidney disease}

CVD is the main cause of death in CKD in both adults and children [19]. Because CKD in adults is caused by hypertensive and diabetic nephropathy, CVD is the main clinical problem already before late stages of CKD [31]. On the contrary, in children with CKD, the clinically evident CVD develops at the late stages of disease, usually in dialyzed patients [32]. The pathogenesis of CVD differs in relation to the stage of CKD. In advanced CKD, CVD is caused by three overlapping processes: atherosclerosis, uremic arteriosclerosis, and uremic cardiomyopathy. In 1974, Lindner et al. reported that hemodialyzed adults suffered from accelerated atherosclerosis [33]. However, although both atherosclerosis and uremic arteriosclerosis share the same risk factors as hypertension, dyslipidemia, hyperhomocysteinemia, and low-level inflammation, etc., the basic mechanisms are different. Atherosclerotic arterial injury starts in the endothelium and the main risk factor is dyslipidemia, which leads to infiltration of arterial wall by lipids, inflammatory reaction, and development of atherosclerotic plaque. Hypercholesterolemia, and especially atherogenic dyslipidemia with elevated low density lipoprotein (LDL) cholesterol, hypertriglyceridemia, and low-high density lipoprotein (HDL) cholesterol, is the most important factor and even in the absence of other factors leads to atherosclerosis. The other risk factors such as hypertension, IR, smoking, etc., which cause mechanical damage to the endothelial layer, facilitate lipids infiltration and accelerate the process [34]. Atherosclerosis is focal and refers to large- and medium-sized arteries. The heart is damaged by repeated episodes of ischemia.

In contrast, uremic arteriopathy begins in the medial layer of the arterial wall (Fig. 1). The process is diffuse and affects the entire arterial tree. The main risk factor of uremic arteriopathy is a low glomerular filtration rate (GFR) with its consequences such as secondary hyperparathyroidism leading to calcium and phosphate homeostasis disturbances. The crucial step in pathogenesis of uremic arteriopathy is the process of differentiation of vascular smooth muscle cells in the medial layer of arterial wall into osteoblast-like cells [35-38]. Arteriopathy accelerates with the start of dialysis and increases with age $[38,39]$. Experimental studies showed that an atherogenic diet caused hyperlipidemia both in subtotally nephrectomized and sham-operated rats but it was more pronounced in uremic rats. However, despite hyperlipidemia with the increase of VLDL and LDL cholesterol concentrations, lipids concentrations were not increased in arterial walls of uremic rats [40]. A comparison of coronary arteries of patients who died with normal renal function and arteries of dialyzed patients showed that uremic patients had greater thickness of the medial layer of coronary arteries. Moreover, lesions in uremic patients were characterized by the presence of calcified plaques and a smaller number of plaques with extracellular lipid deposits [41]. The aortas of uremic patients also had greater calcium and phosphorus content and greater expression of markers of osteoblast phenotype transformation even in noncalcified areas than the aortas of non-uremic patients. It was accompanied by lesser deposition of fetuin $\mathrm{A}$ in uremic aortas which indicates that system of natural inhibitors of calciphylaxis is involved in pathogenesis of uremic arteriopathy [42]. In children with uremic arteriopathy, increased carotid intima media thickness (cIMT) and stiffness of common carotid artery correlated with decreasing GFR [35]. Although low HDL-cholesterol, apoproteins A and B correlated with cIMT, none of these factors was found as an independent predictor of IMT.

The basis for development of uremic cardiomyopathy is diffuse intermyocardiocyte fibrosis (Fig. 2). The main risk factors for uremic cardiomyopathy are the same as for uremic arteriopathy, and both uremic arteriopathy and cardiomyopathy are exaggerated by traditional $\mathrm{CV}$ risk factors and accelerate in CKD stage 5 [43].

The different pathological basis of CV complications caused by uremia and of those caused by metabolic abnormalities typical of MS leading to atherosclerosis explain the discrepant results of treatment with anti-atherosclerotic drugs in relation to stage of CKD.

\section{The prevalence of metabolic syndrome among children and adolescents.}

Using the IDF definition, US National Health and Nutrition Survey data from 1999-2004 showed that among adolescents aged 12-17 years, the prevalence of MS was $4.5 \%$. It increased from $1.2 \%$ in 12 years old to $7.1 \%$ in $16-17$ years old [44]. In the European Youth Heart Study, the prevalence of MS defined according to the IDF was $0.2 \%$ in 10-year-old and $1.4 \%$ in 14-year-old children [45]. Similar data on the prevalence of MS among 10-year-old children were reported in Greece [46]. In Poland, the prevalence of MS among adolescents from urban population ranged from 1.4 to $2.2 \%$, but among children with $\mathrm{PH}$ was ten times higher than in the general population and ranged from 15 to $20 \%[6,8]$.

\section{The prevalence of metabolic abnormalities and metabolic syndrome in CKD}

Metabolic abnormalities, changes in body composition with growth failure, the decrease of LBM, and the increase of 
Fig. 1 Left uremic arteriopathy. Aortic wall of 20-year-old boy dialyzed for 8 years.

Thickening of media of aortic wall. Normal endothelium. Right Atherosclerosis of renal artery in 60-year-old man (courtesy of Dr. W. Grajkowska)
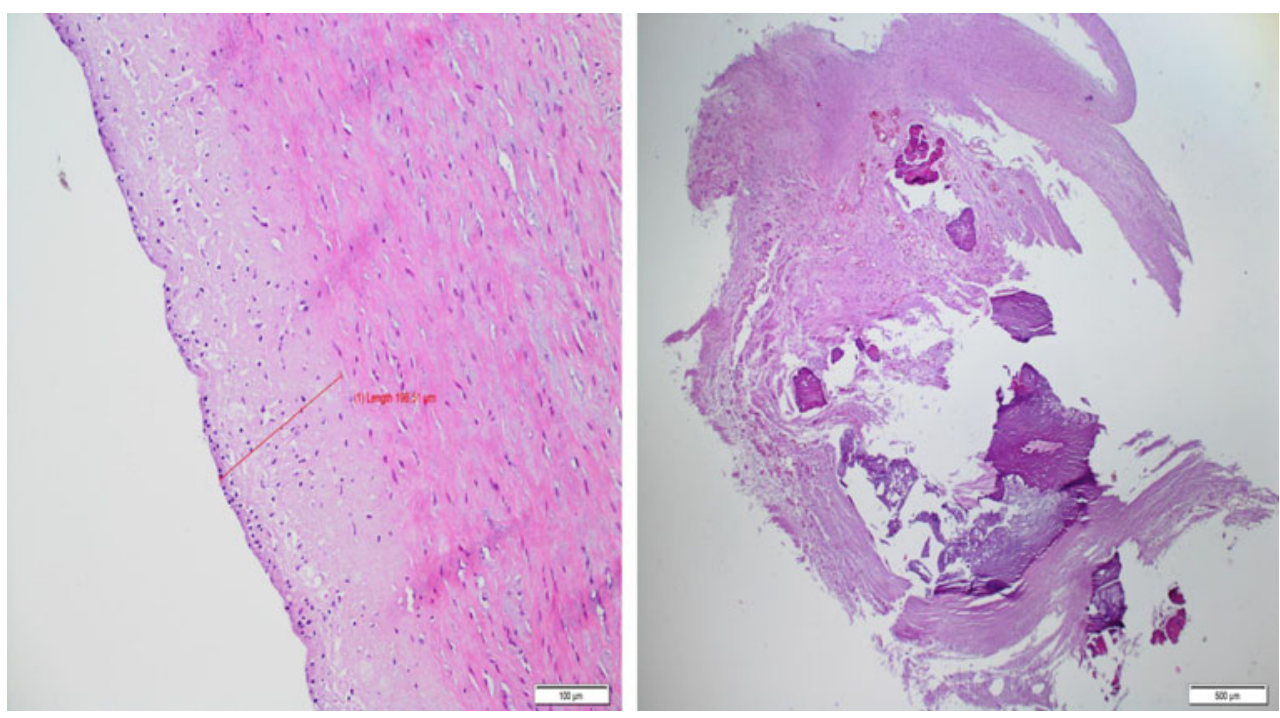

visceral fat correlate with decreasing GFR. However, there are relatively scanty data on the prevalence of MS in children with CKD. Children with CKD are shorter and weigh relatively more than healthy children, which is evident from stage 3 CKD [47-49]. This effect is now modulated by environmental and lifestyle changes and it was reported that children with CKD are more overweight nowadays than two decades ago [50, 51]. Dyslipidemia and glucose intolerance are typical metabolic abnormalities of CKD. Reports from the CKID Study indicate that the most typical abnormality in children with CKD stage 2-4 is hypertriglyceridemia [52]. It was estimated that every $10 \mathrm{ml} / \mathrm{min} / 1.73 \mathrm{~m}^{2}$ decrease of GFR was associated with an increase of serum concentration of TTG by $8 \%$, an increase of LDL cholesterol concentration by $2 \%$, and a decrease of HDL cholesterol concentration by $3 \%$. Proteinuria was associated with these abnormalities and they occurred in children with nephrotic proteinuria twice more often compared to nonproteinuric children.
Another analysis from the CKID Study revealed that $46 \%$ of children with CKD stage 2-4 had hypertension, $44 \%$ had dyslipidemia, $15 \%$ were obese, and $21 \%$ presented with disturbed glucose metabolism. At least three aforementioned cardiovascular risk factors were found in $13 \%$ of patients [53]. Therefore, according to some definitions, the prevalence of MS in this cohort may be estimated as about $13 \%$ what is greater than in general pediatric population. However, this is still much lower than in adults with CKD. Kwan et al. found that in adults with mean GFR $46 \mathrm{ml} / \mathrm{min} / 1.73 \mathrm{~m}^{2}$ the prevalence of MS ranged from 9 to $58 \%$ across BMI values from below 20 to above 35 . In contrast, in adults with mean GFR $87 \mathrm{ml} / \mathrm{min} / 1.73 \mathrm{~m}^{2}$ the prevalence of MS was 1 to $35 \%$ across the same ranges of BMI [54]. Wu et al. found MS in $50.5 \%$ of dialyzed adults when the ATP III definition was used, and in $30.8 \%$ when the IDF definition was used [55]. As in the general population, MS significantly increases CV risk in adults with CKD and even in dialyzed patients. Recent study indicates that abdominal obesity as measured using WC was
Fig. 2 Left normal myocardium. Right Myocardial biopsy of 13-year-old girl dialyzed for 5 years. Myocardiocyte hypertrophy (arrows). Diffuse intermyocardiocyte fibrosis (double arrows) and steatosis. Amount of connective tissue $3 \%$ (normal $1 \%$ ) (courtesy of Dr. W. Grajkowska)
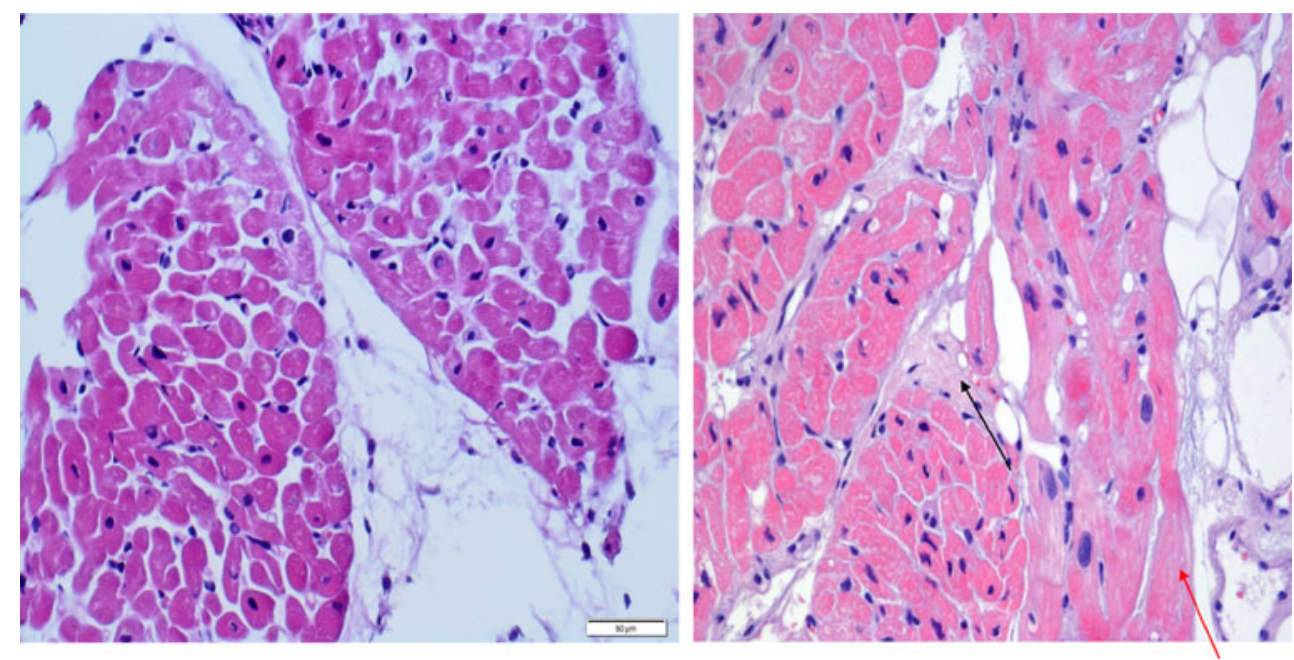
the most significant predictor of $\mathrm{CV}$ events in hemodialyzed adults [55]. It must be pointed out that the relationship between obesity, BMI, and CV risk in dialyzed patients is curvilinear. The CV morbidity and mortality is increased among dialyzed patients with low and even normal BMI in comparison with patients who had elevated BMI. However, detailed analysis revealed that the protective effect of high BMI was limited to patients with normal or high muscle mass [56].

\section{Metabolic syndrome in children after renal transplantation}

Normalization of metabolic abnormalities caused by uremia and even some reversal of uremic arterial and cardiac damage after Rtx depends on GFR of transplanted kidney [57, 58]. However, the immunosuppressive therapy to prevent organ rejection also causes significant metabolic abnormalities such as atherosclerotic dyslipidemia, IR, and the risk of new-onset diabetes after transplantation (NODAT). These abnormalities, typical for MS, are accompanied by visceral obesity and the decrease of LBM. Therefore, the resultant depends on GFR and the side effects of immunosuppressive drugs.

The average prevalence of MS in adults after Rtx is approximately $60-70 \%$. Obesity is the main risk factor for the development of MS after Rtx and MS increases CV risk [59, 60]. The averaged results from pediatric studies indicate that the prevalence of MS significantly increases after Rtx and is higher compared to the general population and in dialyzed children. Wilson et al. reported that the prevalence of MS in children 1 year after Rtx was $37.6 \%$ and two-thirds of them developed MS de novo [61]. Höcker et al. found that the prevalence of MS after Rtx depended on a time from Rtx and the use of corticosteroids (CS) and ranged from $40 \%$ in the first months after Rtx to $20 \%$ after 2 years [62].

Children after Rtx who had MS also had greater left ventricular mass and left ventricular hypertrophy developed in $55 \%$ of them compared with $32 \%$ without MS [61]. The eccentric left ventricular hypertrophy, typical for obesity and MS, was found in $34 \%$ of children with MS, compared with $15 \%$ in children without MS.

MS after Rtx is associated with lower graft survival rates $[63,64]$. Maduran et al. reported that irrespective of CS usage, children who had MS also had significantly lower GFR [65].

CS play a crucial role in the pathogenesis of MS after Rtx. Höcker et al. showed that in patients in whom corticosteroids were withdrawn, the prevalence of MS fell to $5 \%$ after 1 year [62]. Similarly, an exposure to MS factors significantly decreased in this group in comparison to children in whom treatment with CS was continued. The use of greater doses of CS is a derivative of HLA matching and rejection episodes. It was found that MS prevalence was three times lower among recipients of living donor grafts than among recipients of cadaver donor grafts [66].

The most severe metabolic complication of CS after Rtx is NODAT. It seems that the first description of NODAT after Rtx was given by Starzl in 1964 [67]. Although azathioprine usage is also associated with a pancreatic injury, it seems that the prevalence of NODAT increased significantly with the introduction of calcineurin inhibitors (CNI) in mid-eighties of XX century [68]. Cyclosporin (CSA) and especially tacrolimus (TAC) have the potential to directly damage pancreatic $\beta$ cells [69]. A comparison of registry data from the last three decades suggests that the prevalence of NODAT increased from below $10 \%$ in the 1980 s to $20-30 \%$ in the last decade [70]. The US Renal Data System analysis showed that the prevalence of NODAT in transplanted children increased from $2-3 \%$ in the late-1980s to $7.5 \%$ recently [71]. The NAPRTSC report showed an increased prevalence of NODAT in children after Rtx, however the change presented only statistical tendency [72]. Nevertheless, both reports indicate the trend for an increased prevalence of NODAT in transplanted children in the last decades.

The pathogenesis of NODAT is multifactorial and all risk factors for diabetes including CS and CNI play a role. TAC is a stronger risk factor for NODAT than CSA [72]. However, the risk factors for NODAT operate already during dialysis period, and include peritoneal dialysis and obesity [73]. The other risk factor is hyperglycemia during the postoperative period [74]. Peritoneal dialysis, overweight, the usage of CNI and posttransplant hyperglycemia seem all to be risk factors of NODAT.

\section{Metabolic syndrome as a risk factor of CKD in children}

Because the number of nephrons does not increase with increasing body fat, obesity must cause the increase of single-nephron GFR, and the absolute values of GFR should increase as a consequence of increased GFR and filtration fraction. Chagnac et al. reported that GFR was $51 \%$ greater in obese non-diabetic adults than in non-obese, healthy controls. It was associated by proportionally lower (on average $31 \%$ ) increase in renal plasma flow and was accompanied by slightly increased but still in normal range mean arterial pressure. This resulted in a filtration fraction of $17 \%$ in obese in comparison with $15 \%$ in non-obese subjects [75]. Chagnac et al. [75] found that ultrafiltration coefficient did not change. The other finding was that the obese subjects were exposed to the greater glucose and insulin concentrations expressed as the areas under the curves after oral glucose load. The changes in glomerular hemodynamics have been confirmed by clinical observations. MS and its main criteria associate with $\mathrm{CKD}$ 
and are predictors for incident of CKD in adults. The best confirmation of this pathogenical link is hypertensive and diabetic nephropathy as the main causes of CKD [76, 77]. Each criterion of MS is associated with the risk of CKD, however, hypertension has the greatest impact [77]. Most of the studies evaluating the relationship between anthropometrical parameters and the risk of CKD analyzed only BMI. It was found that BMI together with other factors such as diabetes, smoking, and low GFR was associated with the risk of CKD $[78,79]$. However, when other parameters of adiposity such as WC were analyzed, it was shown that the renal risk associated with MS was not associated with increased BMI but with visceral obesity and the probability of incident CKD increased from the lowest to highest WC quartile [80]. Similarly, in the Diabetes Control and Complications Trial, it was found that every $10-\mathrm{cm}$ increase in WC was associated with a $35 \%$ increased risk of incident albuminuria in adults with type 1 diabetes [81].

The time delay between exposure to metabolic abnormalities and kidney injury explains that the first abnormalities are only surrogate markers of progressive CKD. It was found that in obese children and children with non-alcoholic fatty liver disease, exposure to MS criteria impaired glucose tolerance and IR correlated with microalbuminuria and hyperfiltration [82-84]. Kolouridis et al. found that the exposure to the MS criteria correlated positively with GFR. However, GFR decreased when children were exposed to more than four MS criteria [85]. Prospective study of adolescents and young adults (mean age 18 years) found that being overweight, hypertension, and low-HDL cholesterol concentration increased the probability of hyperfiltration 6.6-fold. Moreover, high metabolic risk correlated with hyperfiltration and preceded development of overt nephropathy [86]. The general conclusion is that the first abnormality observed in children with MS is hyperfiltration, and albuminuria develops at later stages followed by the decrease of GFR.

Although the pathogenesis of progressive renal injury related to MS is multifactorial it is at least partly explained by phenomena observed in obesity-related glomerulopathy (ORG). The first report on the relationship between obesity and kidney injury came from Preble who reported in 1923 that obesity was associated with proteinuria [87]. However, Weisinger et al. first described both clinical course and biopsy findings in kidneys of four obese adults who presented with MS and nephrotic proteinuria [88]. Proteinuria decreased with weight loss but in patients who re-gained weight proteinuria reappeared. Cardiac catheterization found an increased right atrial pressure. The renal biopsies revealed segmental sclerosis.

The dominant microscopical finding and probably the first stage of ORG is glomerulomegaly (Fig. 3). The segmental sclerosis beginning in the hilar region is probably the next stage of the disease. In contrast to idiopathic focal segmental glomerular sclerosis (FSGS), ORG-FSGS is associated with much more advanced arteriolosclerosis [14]. The immunofluorescence is usually negative or showed modest IgM and C3 deposits. In some cases of ORGFSGS, electron microscopy showed intramembrane fibrin deposition. The podocytes can be hypertrophied, their processes can be modestly fused, some podocytes can be detached, and neo-membrane is formed. In some reports, reduced podocyte density and number correlated with the severity of proteinuria [89]. Glomeruli cells obtained from biopsy specimens of patients with ORG presented with greater expression of genes related to lipid metabolism, pro-inflammatory cytokines, vascular endothelial growth factor gene, and its receptor 2 [90]. With the rise of the obesity epidemic, ORG is now more often recognized and the incidence of biopsy-proven ORG in adults increased tenfold between 1986 and 2000 [14]. The progressive course of ORG with a decrease of GFR was also observed in obese children [15]. In both adults and children with ORG, proteinuria decreased or even normalized after weight loss and/or RAAS blockade. A normalization of proteinuria has also been reported after bariatric surgery in a morbidly obese girl with biopsy-proven ORG-FSGS [91]. However, histological deterioration was observed despite weight loss and normalization of proteinuria in two biopsy samples taken from a 13-year-old girl at the time of diagnosis of ORG and after 2 years [92].

Historically, the pathogenesis of renal injury in ORG and ORG-FSGS was explained as a consequence of increased venous pressure documented by increased right atrial pressure and modest hypoxemia caused by accompanying sleep apnea [88]. However, the functional studies that documented hyperfiltration with increased intraglomerular pressure and albuminuria preceding overt proteinuria fits well with the hyperfiltration theory. Moreover, an elevated blood pressure, arteriolopathy, and exposure to MS are similar to the pathogenesis of hypertensive nephropathy and nephropathy in type 2 diabetes. Thus, MS will cause an additional burden especially in patients with CKD suffering already from low nephron number due to disease or prematurity.

\section{Treatment of metabolic syndrome and metabolic abnormalities in children with CKD}

Treatment of MS, both in the general population and in children with CKD, is aimed at reversal of IR and normalization of metabolic and hemodynamic abnormalities. It may be achieved by reduction of mitochondrial load by a decrease of substrate availability, a decrease of FA flux to the liver, and an increase in the number of mitochondria [16]. The first aim may be achieved by caloric restriction with dietary modification leading to the decrease of the 
Fig. 3 Renal biopsy from a 14-year-old severely obese girl with proteinuria, hyperuricemia, and metabolic syndrome. She was dialyzed at 20 years old and transplanted at 21. 200× (courtesy of Dr. P. Kluge)

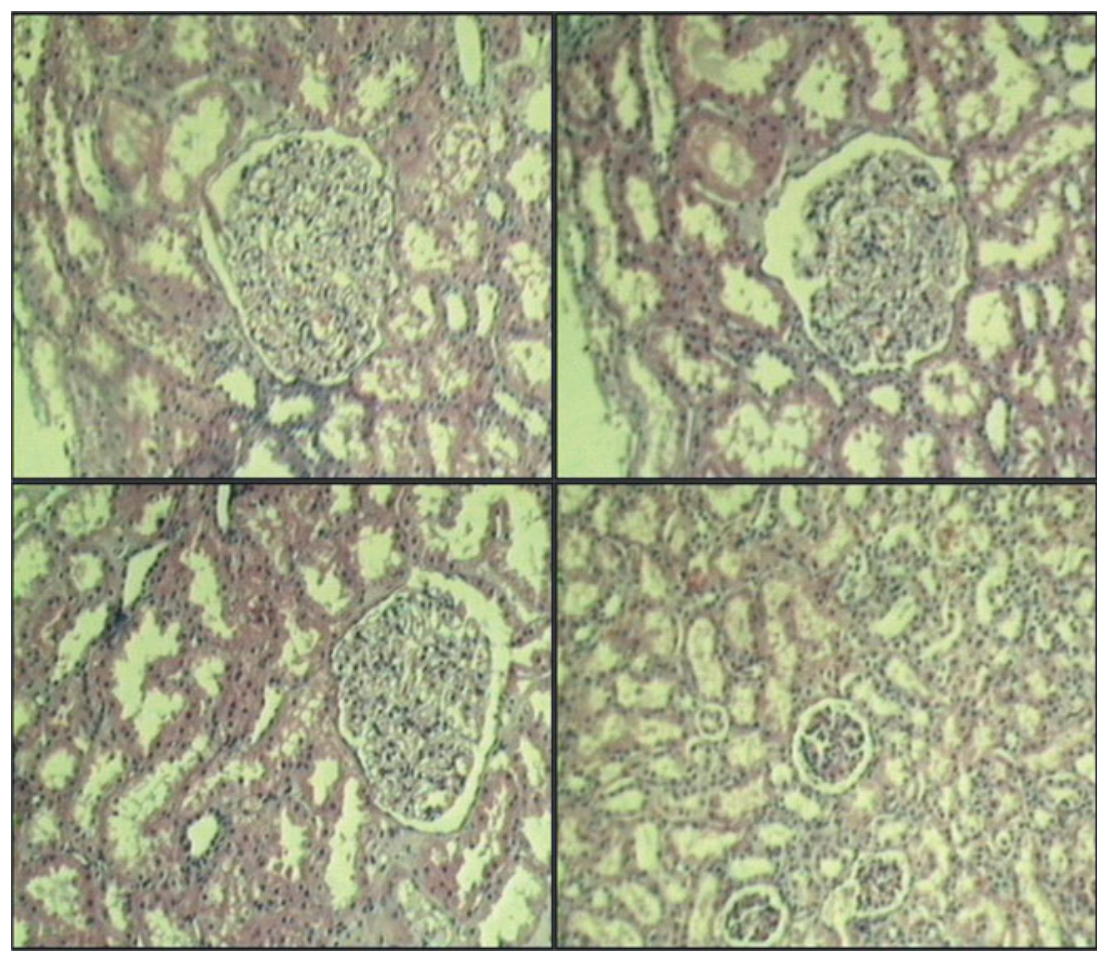

glycemic index. An increased amount of fiber in the food may decrease FA flux. Physical exercise and an increase in LBM lead to the formation of new mitochondria in the liver and in skeletal muscles. Dietary modifications with significant limitations of sugar, and especially of fructose, in the diet, has been found effective in terms of both the normalization of metabolic abnormalities, decrease or stabilization of cIMT, and improvement of endothelial function assessed by flow-mediated dilation (FMD) in children with MS [93, 94]. However, when dietary modifications and physical exercise were combined, FMD of the brachial artery was much more improved. The important observation is that after stopping of an exercise program, FMD decreased to basal values [94]. In adolescents with PH and MS, 1 year of non-pharmacological treatment based on physical activity alone or combined with blockade of RAAS resulted in a decrease of the prevalence of MS by $50 \%$ and the main predictor of improvement was the decrease of WC [6].

\section{Non-pharmacological treatment strategies}

There are only a few reports on the effectiveness of the nonpharmacological treatment of MS in children with CKD or after Rtx. As in other chronic diseases, children with CKD are less physically active and have lower cardiorespiratory fitness assessed as maximal oxygen uptake in comparison with healthy children [95]. The analysis of children and adolescents with CKD, on dialysis and after Rtx, has shown that physical activity was uniformly low in all three groups.
In addition, females were less active than males and older patients, aged 18-20 years, had significantly lower physical activity in comparison with younger patients. Moreover, the results of a standardized 6-min walk distance test were below 2 and 4 standard deviations from the mean of normal values in boys and girls, respectively. The level of physical activity was associated negatively not only with BMI but also positively with maternal education level [96]. In adults with pre-dialysis CKD and on dialysis, effective physical activity treatment caused an increase in cardiorespiratory fitness, a decrease of WC, and an increase in LBM [97]. Such changes associate with an improved biochemical profile [98]. Similarly, in children with CKD, on dialysis and after Rtx, implementation of programs of physical activity resulted in cardiorespiratory fitness improvement, a decrease of blood pressure, and left ventricular mass [99]. However, children after Rtx had to be physically active for at least 3-5 h/week to attain cardiorespiratory fitness of healthy children who led a sedentary life-style (physical activity below $3 \mathrm{~h} /$ week). Although there are no recommendations prepared especially for children with CKD, general pediatric recommendations advise that daily physical activity should be at least $60-90 \mathrm{~min}$ of accepted anaerobic exercise [100]. One of the limiting factors of the anabolic effect of exercise and increase of lean body mass in CKD patients is acidosis [101]. The other limiting factor of lifestyle interventions in children with CKD and after Rtx is non-compliance. It was reported that half of all children after Rtx declined to participate in physical activity program and none of the patients complied with dietary limitations 
[102]. Nevertheless, it must be stressed that the lifestyle interventions in the treatment of MS, although difficult to implement, have been shown to be more efficient than pharmacological treatment [103].

\section{Pharmacological treatment strategies}

Potentially available pharmacological interventions in MS rely on the treatment of dyslipidemia, IR, and arterial hypertension. Although elevated LDL cholesterol is not a criterion of MS, it is commonly observed in children with MS and CKD or after Rtx.

\section{Treatment of dyslipidemia}

Statins lower both total cholesterol, LDL cholesterol, and, to a lesser extent, TTG concentrations. In adults with CKD, statins are effective both in lowering LDL cholesterol and decreasing the incidence of $\mathrm{CV}$ events. However, this beneficial effect was observed only in patients with CKD stage 2-4. In dialyzed patients, statins led to a decrease of LDL cholesterol concentrations but it did not affect CV morbidity and mortality except of patients with diabetes [104, 105]. In the SHARP study, simvastatin with ezetimibe reduced CV events and CV mortality but only those caused by atherosclerosis and not by uremic arteriopathy [106]. Similarly, statins used after Rtx decrease the risk associated with atherosclerosis but the main risk is still related to the low GFR and uremic arteriopathy [107]. It is not unexpected in light of different pathological basis of CVD in CKD and on dialysis, as discussed above. Statins used in children with familial hypercholesterolemia reduced both total and LDL cholesterol and cIMT [108]. Simvastatin used in a non-homogenous group of children with CKD and with modestly reduced GFR led to a reduction of total (by $23 \%$ ), LDL cholesterol (by $34 \%$ ), and TTG (by $21 \%$ ) concentrations [109]. However, in a small cross-over trial of atorvastatin in eight children with CKD and GFR below $60 \mathrm{ml} / \mathrm{min} / 1.73 \mathrm{~m}^{2}$, despite a significant lowering of LDL cholesterol, there was no change in flow-mediated dilation of brachial artery [110].

The drugs of choice in the treatment of hypertriglyceridemia are fibrates or niacin. As in the case of statins, fibrates used in adults with mild to moderate CKD reduced $\mathrm{CV}$ events and, similarly to statins, were renoprotective. However, fibrates also did not reduce CV events in patients on dialysis [111]. There are only a few reports on use of fibrates in children. Nevertheless, a treatment algorithm for the use of fibrates in children was proposed [112]. According to it, in any case, except of TTG levels above $900 \mathrm{mg} / \mathrm{dl}$, the first step should be life-style and dietary modifications with a significant decrease of sugar consumption.
Recommendations on treatment of dyslipidemia in children from high-risk groups

The American Heart Association (AHA) issued recommendations on the treatment of children from high-risk groups including $\mathrm{CKD}$, children with dyslipidemia, and children with MS [17, 102, 113]. The AHA Expert Panel recommended to stratify cardiovascular risk in relation to the family history of CVD and presence of comorbidities such as obesity, hyperglycemia, hypertension, dyslipidemia, and low physical activity. In the case of presence of the above-mentioned comorbidities/risk factors, the AHA recommends treatment (both non-pharmacological and pharmacological) to achieve LDL cholesterol below $100 \mathrm{mg} / \mathrm{dl}$, normoglycemia, normal weight, and normal blood pressure. In patients without additional risk factors, LDL cholesterol should be lowered below $130 \mathrm{mg} / \mathrm{dl}$. The AHA recommends using statins if LDL cholesterol is above $130 \mathrm{mg} / \mathrm{dl}$, despite dietary intervention. Simvastatin and atorvastatin are metabolized by cytochrome P450 3A4 and pravastatin and fluvastatin can be metabolized also by alternative metabolic routes. Involvement of cytochrome P450 in statin metabolism interacts with CNI metabolism, especially with CSA. It was found that in adults after Rtx who were treated with atorvastatin, plasma concentrations of atorvastatin increased sixfold and the CSA area under curve decreased by $9.5 \%$ [114]. According to the 2009 AHA statement on MS in children, fibrates or niacin should be used if triglyceride levels are above $1,000 \mathrm{mg} / \mathrm{dl}$ despite dietary and life-style modifications [18]. Because of the possibility of adverse reactions of both statins and fibrates, especially of rhabdomyolysis, their use should be carefully considered.

Despite the existing recommendations, the use of pharmaceutical products to treat dyslipidemia in children with $\mathrm{CKD}$ and MS is controversial. Due to the different etiology of CKD and pathogenesis of CVD in children with CKD, expert statements do not recommend wide use of statins in children with CKD [115]. Moreover, the recent metaanalyses showed that statins used longer than 1 year increase by $9 \%$ the risk of incident diabetes and intensive treatment increases this risk by additional $12 \%[116,117]$. In children after Rtx and with MS, typical atherogenic dyslipidemia may coexist with MS. Thus, life-style interventions may be successfully combined with statins and/or fibrates. The best option is use of the lowest possible dose of CS or CS-free immunosuppressive protocol, if possible.

\section{Anti-obesity drugs}

Anti-obesity drugs may be the option in children with severe obesity. However, it must be pointed out that only orlistat is licensed for use in the treatment of obese adolescents. Moreover, orlistat has limited efficiency and produces 
significant side effects [118]. Sibutramine, an anti-appetite drug, has been withdrawn because of severe cardiovascular toxicity.

Insulin sensitizers

Theoretically, insulin sensitizers seem to be the best pharmacological option in MS [119]. In contrast to adult studies, there are only a few reports on the use of metformin in children with CKD. Metformin is used in children with MS and glucose levels above $126 \mathrm{mg} / \mathrm{dl}$ when non-pharmacological treatment is ineffective [18]. Because of a relatively safe profile when GFR is above $60 \mathrm{ml} / \mathrm{min} / 1.73 \mathrm{~m}^{2}$, it may be of help in treatment of children with MS and risk of incident CKD. However, use of metformin in CKD is limited by decreased elimination. In patients with GFR below $40 \mathrm{ml} / \mathrm{min} / 1.73 \mathrm{~m}^{2}$, there is more than a $10 \%$ risk of lactic acidosis. Thiazolidinediones, the other insulin sensitizers, may cause hypoglycemia [120]. Nevertheless, the use of thiazolidinediones in diabetic adults on dialysis was associated with significantly lower mortality in patients who were insulin independent but not in those who required insulin treatment [121].

\section{Antihypertensive drugs}

Treatment of elevated blood pressure in children with MS and with CKD or after Rtx should take into account the pathogenetic mechanisms of hypertension, metabolic abnormalities, and potential renoprotective effects. It has been shown both in experimental studies and in clinical trials that blockade of RAAS leads to significant improvement of insulin sensitivity and normalization of metabolic abnormalities [122]. In addition, it was shown that chronic use of ACEi was associated with a lower rate of development of type 2 diabetes in middle age and older adults with arterial hypertension [123]. Thus, the drugs of choice in the treatment of hypertension in children with MS are ACEi or angiotensin 2 receptor type 1 blockers (ARB) [124]. In children with CKD, RAAS inhibitors have also renoprotective effect [125]. However, efficacy of ACEi/ARBs in monotherapy decreases with decrease of GFR and with sodium retention. If monotherapy with ACEi/ARBs is not sufficient, the choice of second and third drug should also take into account metabolic effects.

Dihydropyridine calcium channel blockers have lower renoprotective potential but are devoid of adverse metabolic effects and may be used together with ACEi or ARBs. Similarly, alpha-adrenolytics also have beneficial metabolic profiles. In contrast, beta-adrenolytics aggravate metabolic abnormalities including IR [126]. However, so known vasodilating beta-adrenolytics such as nebivolol have significantly better metabolic profiles in comparison with older beta blockers such as metoprolol [127]. Nevertheless, in children who have volume-dependent hypertension, diuretics may be the last and best option.

\section{Conclusions}

In conclusion, from a practical point of view, the best and safest way of prophylaxis and therapy of MS in children with $\mathrm{CKD}$, on dialysis and after Rtx, is physical activity and dietary modifications. Life-style modifications, when successfully implemented, have greater effects than pharmacological therapy. ACEi or ARBs lower blood pressure, slow progression of $\mathrm{CKD}$, and seem to improve metabolic abnormalities. Pharmacological intervention for dyslipidemia and impaired glucose tolerance/IR should be limited to cases when nonpharmacological treatment is not effective. In children after Rtx minimal dose of CS or CS free protocol is the best option both in prevention and treatment of MS.

\section{Questions (answers are provided following the reference list)}

1. An obligatory criterion of MS according to the IDF definition is:

a) arterial hypertension

b) hypertriglyceridemia

c) low-LDL cholesterol

d) increased waist circumference

e) a and d

2. The prevalence of MS in children after Rtx

a) is lower than in general population

b) is the same as in general population

c) is higher than in general population and the same as in children on dialysis

d) is higher than in general population and higher than in children on dialysis

e) is the same as in children on dialysis

3. The clinical presentation of obesity-related glomerulopathy is

a) severe arterial hypertension, hematuria, proteinuria

b) hematuria with proteinuria

c) isolated proteinuria

d) severe nephrotic syndrome with rapidly declining renal function

e) non-proteinuric, slowly progressive CKD

4. The most important risk factors of NODAT are:

a) preemptive kidney transplantation

b) use of high doses of corticosteroids and calcineurin inhibitors

c) previous long treatment with peritoneal dialysis 

d) CAKUT as primary renal disease
e) b and c

5. Prevention and treatment of MS in CKD and after Rtx should be based on:
a) metformin
b) intensive antihypertensive treatment with ACEi/ARBs plus metformin
c) increased physical activity plus metformin
d) increased physical activity, dietary modifications and $\mathrm{ACEi} / \mathrm{ARBs}$ in the case of elevated blood pressure
e) only ACEi

Open Access This article is distributed under the terms of the Creative Commons Attribution License which permits any use, distribution, and reproduction in any medium, provided the original author(s) and the source are credited.

\section{References}

1. Kannel WB, Brand N, Skinner JJ Jr, Dawber TR, McNamara PM (1967) The relation of adiposity to blood pressure and development of hypertension. The Framingham Study. Ann Intern Med 67:48-59

2. Reaven GM (1988) Banting Lecture 1988. Role of insulin resistance in human disease. Diabetes 37:1956-607

3. Daniels SR, Kimball TR, Morrison JA, Khoury P, Witt S, Meyer RA (1995) Effect of lean body mass, fat mass, blood pressure, and sexual maturation on left ventricular mass in children and adolescents. Statistical, biological, and clinical significance. Circulation 92:3249-3254

4. Poirier P, Lemieux I, Mauriège P, Dewailly E, Blanchet C, Bergeron J, Després JP (2005) Impact of waist circumference on the relationship between blood pressure and insulin. The Quebec Health Survey. Hypertension 45:363-367

5. Yusuf S, Hawken S, Ounpuu S, Bautista L, Franzosi MG, Commerford P, Lang CC, Rumboldt Z, Onen CL, Lisheng L, Tanomsup S, Wangai P Jr, Razak F, Sharma AM, Anand SS, Study Investigators INTERHEART (2005) Obesity and the risk of myocardial infarction in 27,000 participants from 52 countries: a case-control study. Lancet 366:1640-1649

6. Litwin M, Niemirska A, Sladowska-Kozlowska J, Wierzbicka A, Janas R, Wawer ZT, Wisniewski A, Feber J (2010) Regression of target organ damage in children and adolescents with primary hypertension. Pediatr Nephrol 25:2489-2499

7. Ford ES, Li C (2008) Defining the metabolic syndrome in children and adolescents: Will the real definition please stand up? J Pediatr 152:160-4

8. Litwin M, Sladowska J, Antoniewicz J, Niemirska A, Wierzbicka A, Daszkowska J, Wawer ZT, Janas R, Grenda R (2007) Metabolic abnormalities, insulin resistance, and metabolic syndrome in children with primary hypertension. Am J Hypertens 20:875-82

9. Raitakari OT, Juonala M, Rönnemaa T, Keltikangas-Järvinen L, Räsänen L, Pietikäinen M, Hutri-Kähönen N, Taittonen L, Jokinen E, Marniemi J, Jula A, Telama R, Kähönen M, Lehtimäki T, Akerblom HK, Viikari JS (2008) Cohort Profile: The Cardiovascular Risk in Young Finns Study. Int J Epidemiol 37:1220-1226

10. Zimmet P, Alberti KG, Kaufman F, Tajima N, Silink M, Arslanian S, Wong G, Bennett P, Shaw J, Caprio S; IDF Consensus Group (2007) The metabolic syndrome in children and adolescents - an IDF consensus report. Pediatr Diabetes 8:299-306
11. Maric C, Hall JE (2011) Obesity, metabolic syndrome and diabetic nephropathy. Contrib Nephrol 170:28-35

12. Fagot-Campagna A, Pettitt DJ, Engelgau MM, Burrows NR, Geiss LS, Valdez R, Beckles GL, Saaddine J, Gregg EW, Williamson DF, Narayan KM (2000) Type 2 diabetes among North American children and adolescents: an epidemiologic review and a public health perspective. J Pediatr 136:664-72

13. Srivastava $T$ (2006) Nondiabetic consequences of obesity on kidney. Pediatr Nephrol 21:463-470

14. Kambham M, Markowitz GS, Valeri AM, LinJ D'AVD (2001) Obesity-related glomerulopathy: an emerging epidemic. Kidney Int 59:1498-1509

15. Adelman RD, Restaino IG, Alon US, Blowey DL (2001) Proteinuria and focal segmental glomerulosclerosis in severely obese adolescents. J Pediatr 138:481-5

16. Bremer AA, Mietus-Snyder M, Lustig R (2012) Towards unifying hypothesis of metabolic syndrome. Pediatrics 129:557-570

17. Sladowska-Kozlowska J, Litwin M, Niemirska A, Płudowski P, Skorupa E, Janas R (2012) Oxidative stress in hypertensive children before and after 1 year of antihypertensive therapy. Pediatr Nephrol 27:1943-51

18. Steinberger J, Daniels SR, Eckel RH, Hayman L, Lustig RH, McCrindle B, Mietus-Snyder ML (2009) Progress and challenges in metabolic syndrome in children and adolescents. A scientific statement from American Heart Association Atherosclerosis, Hypertension and Obesity in the Young Committee Council on Cardiovascular Disease in The Young; Council on Cardiovascular Nursing; and Council on Nutrition, Physical Activity and Metabolism. Circulation 119:628-647

19. Zhou MS, Schulman IH, Zeng Q (2012) Link between the reninangiotensin system and insulin resistance: implications for cardiovascular disease. Vasc Med 17:330-41

20. Renna NF, Lembo C, Diez E, Miatello RM (2013) Role of reninangiotensin system and oxidative stress on vascular inflammation in insulin resistance model. Int J Hypertens. doi:10.1155/2013/420979

21. Litwin M, Michalkiewicz J, Niemirska A, Gackowska G, Kubiszewska I, Wierzbicka A, Wawer ZT (2010) Janas R (2010) Inflammatory activation in children with primary hypertension. Pediatr Nephrol 25:2489-99

22. Huang RC, Mori TA, Burke V, Newnham J, Stanley FJ, Landau LI, Kendall GE, Oddy WH, Beilin LJ (2009) Synergy between adiposity, insulin resistance, metabolic risk factors, and inflammation in adolescents. Diabetes Care 32:695-701

23. Gunta SS, Mak RH (2013) Ghrelin and leptin pathophysiology in chronic kidney disease. Pediatr Nephrol 28:611-616

24. Arbeiter AK, Büscher R, Petersenn S, Hauffa BP, Mann K, Hoyer PF (2009) Ghrelin and other appetite-regulating hormones in paediatric patients with chronic renal failure during dialysis and following kidney transplantation. Nephrol Dial Transplant 24:643-646

25. Büscher AK, Büscher R, Hauffa BP, Hoyer PF (2010) Alterations in appetite-regulating hormones influence protein-energy wasting in pediatric patients with chronic kidney disease. Pediatr Nephrol 25:2295-301

26. Cheung WW, Paik KH, Mak RH (2010) Inflammation and cachexia in chronic kidney disease. Pediatr Nephrol 25:711-24

27. Suneja M, Murry DJ, Stokes JB, Lim VS (2011) Hormonal regulation of energy-protein homeostasis in hemodialysis patients: an anorexigenic profile that may predispose to adverse cardiovascular outcomes. Am J Physiol Endocrinol Metab 300: E55-64

28. Tsai JP, Tsai CC, Liu HM, Lee CJ, Liou HH, Hsu BG (2011) Hyperleptinaemia positively correlated with metabolic syndrome in hemodialysis patients. Eur J Intern Med 22:e105

29. Szczepanska-Sadowska E, Cudnoch-Jedrzejewska A, Ufnal M, Zera T (2010) Brain and cardiovascular diseases: common 
neurogenic background of cardiovascular, metabolic and inflammatory diseases. J Physiol Pharmacol 61:509-21

30. Zubcevic J, Waki H, Raizada MK, Paton JFR (2011) Autonomicimmune-vascular interaction: an emerging concept for neurogenic hypertension. Hypertension 57:1026-1033

31. Levin A (2003) Clinical epidemiology of cardiovascular disease in chronic kidney disease prior to dialysis. Semin Dial 16:101-5

32. Mitsnefes MM (2008) Cardiovascular complications of pediatric chronic kidney disease. Pediatr Nephrol 23:27-39

33. Lindner A, Charra B, Sherrard DJ, Scribner BH (1974) Accelerated atherosclerosis in prolonged maintenance hemodialysis. N Engl J Med 290:697-701

34. Falk E (2006) Pathogenesis of atherosclerosis. J Am Coll Cardiol 47:C7-C12

35. Litwin M, Wühl E, Jourdan C, Trelewicz J, Niemirska A, Fahr K, Jobs K, Grenda R, Wawer ZT, Rajszys P, Tröger J, Mehls O, Schaefer F (2005) Altered morphologic properties of large arteries in children with chronic renal failure and after renal transplantation. J Am Soc Nephrol 16:1494-500

36. Shroff R, Long DA, Shanahan C (2012) Mechanistic insights into vascular calcification in CKD. J Am Soc Nephrol 24:179-189

37. Shroff RC, Donald AE, Hiorns MP, Watson A, Feather S, Milford D, Ellins EA, Storry C, Ridout D, Deanfield J, Rees L (2007) Mineral metabolism and vascular damage in children on dialysis. J Am Soc Nephrol 18:2996-3003

38. Shroff RC, McNair R, Figg N, Skepper JN, Schurgers L, Gupta A, Hiorns M, Donald AE, Deanfield J, Rees L, Shanahan CM (2008) Dialysis accelerates medial vascular calcification in part by triggering smooth muscle cell apoptosis. Circulation 118:1748-1757

39. Goodman WG, Goldin J, Kuizon BD, Yoon C, Gales B, Sider D, Wang Y, Chung J, Emerick A, Greaser L, Elashoff RM, Salusky IB (2000) Coronary-artery calcification in young adults with endstage renal disease who are undergoing dialysis. N Eng J Med 342:1478-83

40. Horsch A, Ritz E, Heuck CC, Hofmann W, Kuhne E, Bisson M (1981) Atherogenesis in experimental uremia. Atherosclerosis 40:279-89

41. Schwarz U, Buzello M, Ritz E, Stein G, Raabe G, Wiest G, Mall G, Amann K (2000) Morphology of coronary atherosclerotic lesions in patients with end-stage renal failure. Nephrol Dial Transplant 15:218-223

42. Koleganova N, Piecha G, Ritz E, Schirmacher P, Müller A, Meyer HP, Gross ML (2009) Arterial calcification in patients with chronic kidney disease. Nephrol Dial Transplant 24:2488-2496

43. Litwin M, Kawalec W, Latoszyńska J, Grenda R, Smirska E (1994) Cardiac systolic and diastolic function in children on hemodialysis and continuous ambulatory peritoneal dialysis. Contrib Nephrol 106:114-8

44. Ford ES, Li C, Zhao G, Pearson WS, Mokdad AH (2008) Prevalence of the metabolic syndrome among U.S. adolescents using the definition from the International Diabetes Federation. Diabetes Care 31:587-589

45. Ekelund U, Anderssen S, Andersen LB, Riddoch CJ, Sardinha LB, Luan J, Froberg K, Brage S (2009) Prevalence and correlates of metabolic syndrome in population-based sample of European youth. Am J Clin Nutr 89:90-96

46. Kelishadi R (2007) Childhood overweight, obesity, and the metabolic syndrome in developing countries. Epidemiol Rev 29:62-76

47. Foster BJ, Kalkwarf HJ, Shults J, Zemel BS, Wetzsteon RJ, Thayu M, Foerster DL, Leonard MB (2011) Association of chronic kidney disease with muscle deficits in children. J Am Soc Nephrol 22:377-86

48. V1 J, Wong J, Kaskel FJ, Pierson RN (2008) Changes in body composition of children with chronic renal failure on growth hormone. Pediatr Nephrol 14:695-700
49. Rashid R, Nail E, Smith W, King D, Beattie TJ, Murphy A, Ramage IJ, Maxwell H, Ahmed SF (2006) Body composition and nutritional intake in children with chronic kidney disease. Pediatr Nephrol 21:1730-8

50. Filler G, Reimao SM, Kathivarei A, Grimmer J, Feber J, Drukker A (2007) Pediatric nephrology patients are overweight: 20 years experience in a single Canadian tertiary pediatric nephrology clinic. In Urol Nephrol 39:1235-1240

51. Filler G, Payne RP, Orrbine E, Clifford T, Drukker A, McLaine PN (2005) Changing trends in the referral patterns of pediatric nephrology patients. Pediatr Nephrol 20:603-608

52. Saland JM, Pierce CB, Mitsnefes MM, Flynn JT, Goebel J, Kupferman JC, Warady BA, Furth SL, CKiD Investigators (2010) Dyslipidemia in children with chronic kidney disease. Kidney Int 78:1154-63

53. Furth SL, Abraham AG, Jerry-Fluker J, Schwartz G, Benfield M, Kaskel F, Wong C, Mak R, Moxey-Mims M, Warady BA (2011) Metabolic Abnormalities, CVD Risk Factors and GFR Decline in Children with CKD. Clin J Am Soc Nephrol 6:2132-2140

54. Kwan BCH, Murtaugh MA, Beddhu S (2007) Associations of body size with metabolic syndrome and mortality in moderate chronic kidney disease. Clin J Am Soc Nephrol 2(5):992-8

55. Wu CC, Liou HH, Su PF, Chang MY, Wang HH, Chen MJ, Hung SY (2011) Abdominal obesity is the most significant metabolic syndrome component predictive of cardiovascular events in chronic hemodialysis patients. Nephrol Dial Transplant 26:3689-95

56. Beddhu S, Pappas LM, Ramkumar N, Samore M (2003) Effect of body size and body composition on survival in hemodialysis patients. J Am Soc Nephrol 14:2366-2372

57. Krmar RT, Balzano R, Jogestrand T, Cedazo-Minguez A, Englund MS, Berg UB (2008) Prospective analysis of carotid arterial wall structure in pediatric renal transplants with ambulatory normotension and in treated hypertensive recipients. Pediatric Transplant 12:412-9

58. Litwin M, Wühl E, Jourdan C, Niemirska A, Schenk JP, Jobs K, Grenda R, Wawer ZT, Rajszys P, Mehls O, Schaefer F (2008) Evolution of large-vessel arteriopathy in paediatric patients with chronic kidney disease. Nephrol Dial Transplant 23:2552-7

59. Armstrong KA, Campbell SB, Hawley CM, Nicol DL, Johnson DW, Isbel NM (2005) Obesity is associated with worsening cardiovascular risk factor profiles and proteinuria progression in renal transplant recipients. Am J Transplant 11:2710-8

60. Hricik DE (2011) Metabolic syndrome in kidney transplantation: management of risk factors. Clin J Am Soc Nephrol 6(7):1781-5

61. Wilson AC, Greenbaum LA, Barletta GM, Chand D, Lin JJ, Patel HP, Mitsnefes M (2010) High prevalence of the metabolic syndrome and associated left ventricular hypertrophy in pediatric renal transplant recipients. Pediatr Transplant 14:52-60

62. Höcker B, Weber LT, Feneberg R, Drube J, John U, Fehrenbach H, Pohl M, Zimmering M, Fründ S, Klaus G, Wühl E, Tönshoff B (2010) Improved growth and cardiovascular risk after late steroid withdrawal: 2-year results of a prospective, randomised trial in paediatric renal transplantation. Nephrol Dial Transplant 25:617-24

63. Porrini E, Delgado P, Bigo C, Alvarez A, Cobo M, Checa MD, Hortal L, Fernández A, García JJ, Velázquez S, Hernández D, Salido E, Torres A (2006) Impact of metabolic syndrome on graft function and survival after cadaveric renal transplantation. Am J Kidney Dis 48:134-142

64. de Vries AP, Bakker SJ, van Son WJ, van der Heide JJ, Ploeg RJ, The HT, de Jong PE, Gans RO (2004) Metabolic syndrome is associated with impaired long-term renal allograft function; not all component criteria contribute equally. Am J Transplant 4:1675-1683

65. Maduram A, John E, Hidalgo G, Bottke R, Fornell L, Oberholzer J, Benedetti E (2010) Metabolic syndrome in pediatric renal transplant recipients: comparing early discontinuation of steroids vs. steroid group. Pediatr Transplant 14:351-7 
66. Guadarrama O, López M, Valverde-Rosas S, Velásquez-Jones L, Romero B, Toussaint G, Medeiros M (2009) Prevalence of metabolic syndrome and obesity in renal transplanted Mexican children. Pediatr Transplant 13:579-84

67. Starzl TE (1964) Experience in renal transplantation. WB Saunders, Philadelphia, pp 161-221

68. Bodziak KA, Hricik DE (2009) New-onset diabetes mellitus after solid organ transplantation. Transplant Int 22:519-30

69. Fioretto P, Najafian B, Sutherland DE, Mauer M (2011) Tacrolimus and cyclosporine nephrotoxicity in native kidneys of pancreas transplant recipients. Clin J Am Soc Nephrol 6:101-6

70. Pham PT, Pham PM, Pham SV, Pham PA, Pham PC (2011) New onset diabetes after transplantation (NODAT): an overview. Diabetes Metab Syndr Obes 4:175-86

71. Burroughs TE, Swindle JP, Salvalaggio PR, Lentine KL, Takemoto SK, Bunnapradist S, Brennan DC, Schnitzler MA (2009) Increasing incidence of new-onset diabetes after transplant among pediatric renal transplant patients. Transplantation 15:367-73

72. Al-Uzri A, Stablein DM, Cohn R (2001) Posttransplant diabetes mellitus in pediatric renal transplant recipients: a report of the North American Pediatric Renal Transplant Cooperative Study (NAPRTCS). Transplantation 72:1020

73. Madziarska K, Klinger M (2012) New onset post-transplant diabetes mellitus begins in the dialysis period. J Ren Nutr 22:162-5

74. Chakkera HA, Knowler WC, Devarapalli Y, Weil EJ, Heilman RL, Dueck A, Mulligan DC, Reddy KS, Moss AA, Mekeel KL, Mazur MJ, Hamawi K, Castro JC, Cook CB (2010) Relationship between inpatient hyperglycemia and insulin treatment after kidney transplantation and future new onset diabetes mellitus. Clin J Am Soc Nephrol 5:1669-75

75. Chagnac A, Weinstein T, Korzets A, Ramadan E, Hirsch J, Gafter U (2000) Glomerular hemodynamics in severe obesity. Am J Physiol Renal Physiol 278:F817-F822

76. Chen J, Muntner P, Hamm H, Jones DW, Batuman V, Fonseca V, Whelton P, He J (2004) The metabolic syndrome and chronic kidney disease in US adults. Ann Intern Med 140:167-174

77. Thomas G, Sehgal AR, Kashyap SR, Srinivas TR, Kirwan JP, Navaneethan SD (2011) Metabolic Syndrome and Kidney Disease: A Systematic Review and Meta-analysis. Clin J Am Soc Nephrol 6:2364-2373

78. Fox CS, Larson MG, Leip EP, Culleton B, Wilson PW, Levy D (2004) Predictors of new-onset kidney disease in a communitybased population. JAMA 291:844-850

79. Ejerblad E, Fored CM, Lindblad P, Fryzek J, McLaughlin JK, Nyren O (2006) Obesity and risk for chronic renal failure. J Am Soc Nephrol 17:1695-1702

80. Noor N, Hosseinpanah F, Nasiri AD, Azizi F (2009) Comparison of overall obesity and abdominal obesity in predicting chronic kidney disease incidence among adults. J Ren Nutr 19:228-37

81. De Boer IH, Sibley SD, Kestenbaum B (2007) Central obesity, incident microalbuminuria and change in creatinine clearance in the diabetes interventions and complications study. J Am Soc Nephrol 18:235-43

82. Csernus K, Lanyi E, Erhardt E, Molnar D (2005) Effect of childhood obesity and obesity-related cardiovascular risk factors on glomerular and tubular protein excretion. Eur J Pediatr 164:44-9

83. Burgert TS, Dziura J, Yeckel C, Taksali SE, Weiss R, Tamborlane W, Caprio S (2006) Microalbuminuria in pediatric obesity: prevalence and relation to other cardiovascular risk factors. Int J Obes 30:273-80

84. Manco M, Ciampalini P, DeVito R, Vania A, Cappa M, Nobili V (2009) Albuminuria and insulin resistance in children with biopsy proven non-alcoholic fatty liver disease. Pediatr Nephrol 24:1211-7

85. Kolouridis E, Georgalidis K, Kostimpa I, Kolouridis I, Krokida A, Houliara D (2010) Metabolic syndrome risk factors and estimated glomerular filtration rate among children and adolescents. Pediatr Nephrol 25:491-498
86. Tomaszewski M, Charchar FJ, Maric C, McClure J, Crawford L, Grzeszczak W, Sattar N, Zukowska-Szczechowska E, Dominiczak AF (2007) Glomerular hyperfiltration: a new marker of metabolic risk. Kidney Int 71:816-21

87. Preble WE (1923) Obesity: observations on one thousand cases. Boston Med Surg J 188:617-21

88. Wiesinger JR, Kepmson RL, Edlridge FL, Swenson RS (1974) The nephrotic syndrome: complication of massive obesity. Ann Intern Med 81:440-447

89. Chen HM, Liu ZH, Zeng CH (2006) Podocyte lesions in patients with obesity-related glomerulopathy. Am J Kid Dis 48:772-779

90. Wu Y, Lin Z, Xiang Z, Zeng C, Chen Z, Ma X, Li L (2006) Obesity-related glomerulopathy: insights from gene expression profiles of the glomeruli derived from biopsy samples. Endocrinology 147:44-50

91. Fowler SM, Kon V, Richards WO, Fogo AB, Hunley TE (2009) Obesity-related focal and segmental glomerulosclerosis: normalization of proteinuria in an adolescent after bariatric surgery. Pediatr Nephrol 24:851-855

92. Gregoraki-Angelaki H, Stergiou N, Manolaki N, Nakopoulou L, Syriopoulou VP, Roma-Giannikou R (2010) Histological deterioration of obesity-related glomerulopathy despite the loss of proteinuria with weight loss reduction. Pediatr Nephrol 25:1573-1574

93. Nemet D, Barkan S, Epstein Y, Friedland O, Kowen G, Eliakim A (2005) Short- and long-term beneficial effects of a combined dietary-behavioral-physical activity intervention for the treatment of childhood obesity. Pediatrics 115:e443-e449

94. Woo KS, Chook P, Yu CW, Sung RY, Qiao M, Leung SS, Lam CW, Metreweli C, Celermajer DS (2004) Effect of diet and exercise on obesity-related vascular dysfunction in children. Circulation 109:1981-1986

95. Tangeraas T, Midtvedt K, Fredriksen PM, Cvancarova M, Mørkrid L, Bjerre A (2010) Cardiorespiratory fitness is a marker of cardiovascular health in renal transplanted children. Pediatr Nephrol 25:2343-50

96. Akber A, Portale AA, Johanssen KL (2012) Pedometer-assessed physical activity in children and young adults with CKD. Clin J Am Soc Nephrol 7:720-726

97. Kouidi E, Grekas D, Deligiannis A, Tourkantonis A (2004) Outcomes of long-term exercise training in dialysis patients: comparison of two training programs. Clin Nephrol 61(Suppl 1):S31-8

98. Moinuddin I, Leehey DJ (2008) A comparison of aerobic exercise and resistance training in patients with and without chronic kidney disease. Adv Chronic Kidney Dis 15:83-96

99. Lubriano R, Tancredi G, Bellelli E, Gentile I, Scolari S, Masciangelo R, De Castro G, Versacci P, Elli M (2012) Influence of physical activity on cardiorepsiratory fitness in children after renal transplantation. Nephrol Dial Transplant 27:1677-1681

100. Kavey R-E W, Allada V, Daniels SR, Hayman LL, McCrindle BW, Newburger JW, Parekh RS, Steineberger J (2006) Cardiovascular risk reduction in high risk pediatric patients: a scientific statement from the American Heart Association Expert Panel on Population and Prevention Science; The Councils on Cardiovascular Disease in the Young, Epidemiology and Prevention, Nutrition, Physical Activity, and the Kidney in Heart Disease; and the Interdisciplinary Working Group on Quality of Care and Outcomes research: Endorsed by the American Academy of Pediatrics. Circulation 114:2710-2738

101. Clapp EL, Bevington A (2011) Exercise-induced biochemical modifications in muscle in chronic kidney disease: occult acidosis as a potential factor limiting the anabolic effect of exercise. J Ren Nutr 21:57-60

102. Delluchi A, Marin V, Trabucco G, Azocar M, Salas P, Guttierez E, Guardia S, Cano F, Cumsille A (2001) Dyslipidemia and 
dietary modification in Chilean renal pediatric transplantation. Transplant Proc 33:2008-2013

103. Dunkley AJ, Charles K, Gray LJ, Camosso-Stefinovic J, Davies MJ, Khunti K (2012) Effectiveness of interventions for reducing diabetes and cardiovascular disease risk in people with metabolic syndrome: systematic review and mixed treatment comparison meta-analysis. Diabetes Obes Metab 14:616-25

104. Fellstrome BC, Jardin AG, Schmieder RE, for the AURORA Study Group (2009) Rosuvastatin and cardiovascular events in patients undergoing hemodialysis. N Eng J Med 360:1395-1407

105. Holdaas H, Holme I, Schmieder RE, Jardine AG (2011) Fellstrom BC; AURORA Study Group (2011) Rosuvastatin in diabetic hemodialysis patients. J Am Soc Nephrol 22:1335-1341

106. Baigent C, Landray MJ, Reith C, Emberson J, Wheeler DC, Tomson C, Wanner C, Krane V, Cass A, Craig J, Neal B, Jiang L, Hooi LS, Levin A, Agodoa L, Gaziano M, Kasiske B, Walker R, Massy ZA, Feldt-Rasmussen B, Krairittichai U, Ophascharoensuk V, Fellström B, Holdaas H, Tesar V, Wiecek A, Grobbee D, de Zeeuw D, Grönhagen-Riska C, Dasgupta T, Lewis D, Herrington W, Mafham M, Majoni W, Wallendszus K, Grimm R, Pedersen T, Tobert J, Armitage J, Baxter A, Bray C, Chen Y, Chen Z, Hill M, Knott C, Parish S, Simpson D, Sleight P, Young A, Collins R, Investigators SHARP (2011) The effects of lowering LDLcholesterol with simvastatin plus ezetimibe in patients with chronic kidney disease (Study of Heart and Renal Protection): a randomized-controlled trial. Lancet 377:2181-92

107. Jardine AG, Gaston RS, Fellstrom BC, Holdaas H (2011) Prevention of cardiovascular disease in adults recipients of kidney transplants. Lancet 378:1419-27

108. Rodenburg J, Vissers MN, Wiegman A, van Trotsenburg AS, van der Graaf A, de Groot E, Wijburg FA, Kastelein JJ, Hutten BA (2007) Statin treatment in children with familial hypercholesterolemia: the younger, the better. Circulation 116:664-668

109. Garcia-de-la-Puente S, Arredondo-Garcia JL, Bojourquez-Ochoa A, Maya ER, del Pilar P-MM (2009) Efficacy of simvastatin in children hyperlipidemia secondary to kidney disorders. Pediatr Nephrol 24:1205-1210

110. Mackie FE, Rosenberg AW, Hermer JA, Kainer G, Celermajer DS (2010) HMG-CoA reductase inhibitors and endothelial function in children with chronic kidney disease - a pilot study. Acta Paediatrica 99:457-459

111. Jun M, Zhu B, Tonelli M, Jardine MJ, Patel A, Neal B, Liyanage T, Keech A, Cass A, Perkovic (2012) Effects of fibrates in kidney disease. A systematic review. J Am Coll Cardiol 60:2061-2071

112. Manlhiot C, Larsson P, Gurofsky RC, Smith RW, Fillingham C, Clarizia NA, Chahal N, Clarke JT, McCrindle BW (2009) Spectrum and management of hypertriglyceridemia among children in clinical practice. Pediatrics 123:458-465

113. Daniels SR, Greer FR (2008) Lipid screening and cardiovascular health in children. Pediatrics 122:198-208

114. Asberg A, Hartmann A, Fieldsa E, Bergan S (2001) Holdaas H (2001) Bilateral pharmacokinetic interaction between cyclosporine $\mathrm{A}$ and atorvastatin in renal transplant recipients. Am J Transplant 1:382-386

115. Tullus K (2012) Dyslipidemia in children with CKD: should we treat with statins? Pediatr Nephrol 27:357-362

116. Sattar N, Preiss D, Murray HM, Welsh P, Buckley BM, de Craen AJ, Seshasai SR, McMurray JJ, Freeman DJ, Jukema JW, Macfarlane PW, Packard CJ, Stott DJ, Westendorp RG, Shepherd J, Davis BR, Pressel SL, Marchioli R, Marfisi RM, Maggioni AP, Tavazzi L, Tognoni G, Kjekshus J, Pedersen TR, Cook TJ, Gotto AM, Clearfield MB, Downs JR, Nakamura H, Ohashi Y, Mizuno K, Ray KK, Ford I (2010) Statins and risk of incident diabetes: a collaborative meta-analysis of randomised statin trials. Lancet 375:735-742
117. Preiss D, Seshasai SR, Welsh P, Murphy SA, Ho JE, Waters DD, DeMicco DA, Barter P, Cannon CP, Sabatine MS, Braunwald E, Kastelein JJ, de Lemos JA, Blazing MA, Pedersen TR, Tikkanen MJ, Sattar N, Ray KK (2011) Risk of incident diabetes with intensive-dose compared with moderate-dose statin therapy: a meta-analysis. JAMA 305:2556-2564

118. Chanoine JP, Hampl S, Jensen C, Boldrin M, Hauptman J (2005) Effect of orlistat on weight and body composition in obese adolescents: a randomized controlled trial. JAMA 293:28732883

119. Sabin MA, Magnussen CG, Juonala M, Cowlej MA, Shield JPH (2012) The role of pharmacotherapy in the prevention and treatment of paediatric metabolic syndrome in - implications for the long-term-health. Pharm Res 65:397-401

120. Duong JK, Roberts DM, Furlong TJ, Kumar SS, Greenfield JR, Kirkpatrick CM, Graham GG, Williams KM, Day RO (2010) Metformin therapy in patients with chronic kidney disease. Diabetes Obes Metab 14:963-5

121. Brunelli SM, Thadhani R, Ikizler TA, Feldman HI (2009) Thiazolidinedione use is associated with better survival in hemodialyzed patients with non-insulin dependent diabetes. Kidney Int 75:961-968

122. Kalupahana NA, Moustaid-Moussa N (2012) The reninangiotensin system: the link between obesity, inflammation and insulin resistance. Obes Rev 13:136-149

123. Vermes E, Ducharme A, Bourassa MG, Lessard M, White M, Tardif JC (2003) Enalapril reduces the incidence of diabetes in patients with chronic heart failure: insight from Studies of the Left Ventricular Dysfunction (SOLVD). Circulation 107:1291-1296

124. Lurbe E, Cifkova R, Cruickshank JK, Dillon MJ, Ferreira I, Invitti C, Kuznetsova T, Laurent S, Mancia G, Morales-Olivas F, Rascher W, Redon J, Schaefer F, Seeman T, Stergiou G, Wühl E, Zanchetti A; European Society of Hypertension (2009) Management of high blood pressure in children and adolescents: recommendations of the European Society of Hypertension. J Hypertens 27:1719-1742

125. ESCAPE Trial Group, Wühl E, Trivelli A, Picca S, Litwin M, Peco-Antic A, Zurowska A, Testa S, Jankauskiene A, Emre S, Caldas-Afonso A, Anarat A, Niaudet P, Mir S, Bakkaloglu A, Enke B, Montini G, Wingen AM, Sallay P, Jeck N, Berg U, Caliskan S, Wygoda S, Hohbach-Hohenfellner K, Dusek J, Urasinski T, Arbeiter K, Neuhaus T, Gellermann J, Drozdz D, Fischbach M, Möller K, Wigger M, Peruzzi L, Mehls O, Schaefer F (2009) Strict blood-pressure control and progression of renal failure in children. N Engl J Med 361(17):1639-1650

126. Carella AM, Antonucci G, Conte M, Di Pumpo M, Giancola A, Antonucci E (2010) Antihypertensive treatment with betablockers in the metabolic syndrome: a review. Curr Diabetes Rev 6:215-221

127. Ayers K, Byrne LM, DeMatteo A, Brown NJ (2012) Differential effects of nebivolol and metoprolol on insulin sensitivity and plasminogen activator inhibitor in the metabolic syndrome. Hypertension 59:893-898

\section{Answers;}

Q1: d

Q2: d

Q3: c

Q4: e

Q5: d 